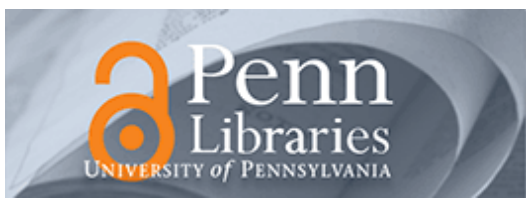

University of Pennsylvania ScholarlyCommons

Department of Anthropology Papers

Department of Anthropology

4-1969

\title{
Politics, Kinship, and Ecology in Southeast Persia
}

Brian Spooner

University of Pennsylvania, spooner@sas.upenn.edu

Follow this and additional works at: http://repository.upenn.edu/anthro_papers

Part of the Anthropology Commons, and the Demography, Population, and Ecology Commons

\section{Recommended Citation}

Spooner, B. (1969). Politics, Kinship, and Ecology in Southeast Persia. Ethnology, 8 (2), 139-152. https://doi.org/10.2307/3772976

This paper is posted at ScholarlyCommons. http://repository.upenn.edu/anthro_papers/59

For more information, please contact libraryrepository@pobox.upenn.edu. 


\title{
Politics, Kinship, and Ecology in Southeast Persia
}

\begin{abstract}
The Iranian plateau is an ideal area for investigating the relationship be? tween ecological and sociological factors because of its stark aridity, on the one hand, and its historical role as a meeting place of ethnic and cultural movements on the other. The part of the plateau which forms the southeast corner of Persia is particularly interesting from this point of view. Over an area of some 200,000 square kilometers the great majority of the population, which numbers about half a million and includes both peasants and nomads, call themselves Baluch. Most, but not all of them, speak a dialect of Baluchi as their native tongue, and practically all adults speak it as a lingua franca. However, their political and social organization shows important variations, and there are striking geographical variations in the country they inhabit. It is unusual to find such wide variations among people who consider themselves one society. This paper shows how the variations in political and social organization in the area may be related to variations in human ecology. I wish to demonstrate that in this area of Persia, where political leadership relies on an income from settled agriculture, there is a definite social differentiation into classes and cognatic values are given to kin relationships, whereas leadership which relies primarily on nomadic pastoralism works through a structure of agnatic kin relationships without class differentiation.
\end{abstract}

\section{Disciplines}

Anthropology | Demography, Population, and Ecology | Social and Behavioral Sciences 


\title{
Politics, Kinship, and Ecology in Southeast Persia
}

\author{
Brian Spooner \\ University of Pennsylvania
}

The Iranian plateau is an ideal area for investigating the relationship between ecological and sociological factors because of its stark aridity, on the one hand, and its historical role as a meeting place of ethnic and cultural movements on the other. The part of the plateau which forms the southeast corner of Persia is particularly interesting from this point of view. Over an area of some 200,000 square kilometers the great majority of the population, which numbers about half a million and includes both peasants and nomads, call themselves Baluch. Most, but not all of them, speak a dialect of Baluchi as their native tongue, and practically all adults speak it as a lingua franca. However, their political and social organization shows important variations, and there are striking geographical variations in the country they inhabit. It is unusual to find such wide variations among people who consider themselves one society. This paper shows how the variations in political and social organization in the area may be related to variations in human ecology. I wish to demonstrate that in this area of Persia, where political leadership relies on an income from settled agriculture, there is a definite social differentiation into classes and cognatic values are given to kin relationships, whereas leadership which relies primarily on nomadic pastoralism works through a structure of agnatic kin relationships without class differentiation. ${ }^{1}$

The first section of the paper describes briefly the more significant aspects of the political and social organization, the differences in behavior relating to kinship, and the more important ecological factors. I also indicate the structural relationship between communities following different practices. The second section introduces two special cases which illustrate partial transitions between the two poles of structural variation. The final section seeks, by means of a diachronic model based on historical reconstruction, to show the dynamic relationship between the various differences in practice. The material, and to some extent the argument, is complicated by the fact that beginning in 1928 the central government has followed a formal policy of substituting its own administration for the traditional political organization. Until about fifteen years ago the effects of this policy seem to have been minimal, but during the last decade or so traditional Baluch leaders have lost most of their freedom of action. 


\section{Ethnology}

\section{General EthNogRaphy}

The most conscious sociological divisions among the Persian Baluch are into tribes $(z \bar{a} t)$, which are in many cases subdivided. Membership in a tribe is inherited patrilineally. A more significant-though less conscioussociological division is into social categories, which, since they are the main factor in determining status, may be called classes. There is no word for class in Baluchi, only names for each social category, namely, häkomzät, baluch, ${ }^{2}$ shahri, and gholäm. Secondary status or subclass distinctions are also made within these four broad classes, usually on the basis of tribe or subtribe. Class membership is also hereditary, but according to bilateral principles, and in cases of mixed parentage the lowest common denominator prevails. There are some cases where a tribe which is baluch or shahri by class has a subtribe descended from it which has become häkomzät, but apart from this possibility tribes do not overlap classes.

A complication in the analysis of these class categories is that in general baluch and shahri cannot be said to stand in a hierarchical relationship. In any given community or area all the baluch may have a higher status rating than all the shahri, or vice versa, but it is more usual for some of the shahri tribes or subtribes to have a higher and some a lower status rating than the baluch of the area. In general, there is a wide status differentiation within the shahri class but much less differentiation within the baluch class.

These terms signify basically occupational divisions, or divisions according to way of life and livelihood. The häkomzät class comprises all of a certain type of chief (häkom) and their more immediate families. The baluch are nomadic pastoralists. The shahri are peasants-always possessing a certain amount of land and/or water, though often not enough to insure economic independence. The gholām were formerly slaves, ${ }^{3}$ and may now be generally characterized as a low social class with no property, usually distinguishable by their darker skin color. This situation obviously shows much resemblance to the caste system of the Indian subcontinent, and a similar situation in Swat has been directly compared to the caste system (Barth 1962). In our area, however, the situation is less conscious, and its justification is historical precedent rather than ritual or religious doctrine. Wherever possible, class difference and individual identity are expressed in tribal terms. But a tribe is often not a political or social unit. It may be spread through a number of villages or nomadic groups over a large area. Similarly, any one peasant community may be composed of members of one or many tribes, and of one or more classes, and a nomadic area controlled by one high-status family may contain groups from tribes which extend through several other areas. Conditions can occur whereby individuals or subtribes change their subclass, or even their class, over a period of time, but this is rare. Intermarriage-at least between the three higher classes-is not so rare, though a girl should never marry down, and it is unheard of for a häkomzät girl to marry outside her class. 
The preferred marriage partner is a cousin, real or classificatory. People invariably claim to prefer the patrilateral parallel cousin when asked specifically, but practice shows no definite preference. The terminology distinguishes only between cousins born of aunts and cousins born of uncles, and makes no distinction at all between patrilateral and matrilateral relatives. It is of the Eskimo type and is identical for all who speak Baluchi within the area. However, some tribes follow a strict patrilineal reckoning of descent, give no inheritance to daughters, and ascribe little importance to the origin of the mother, whereas others reckon descent bilaterally, give equal inheritance shares to sons and daughters, and ascribe equal importance to the origin of the mother. ${ }^{4}$ Where the father is an important leader and it is likely that the eldest son will take his place, it is usual for the father to set aside an extra portion for him before the general division of the inheritance. This must be done with the consent of the other sons and daughters, and is known as mirwandi, which may be roughly translated as the "leadership share." Such leaders, even though their kinship practice may be entirely cognatic, always remember their agnatic genealogy back to the ancestor who brought the family into the area. This is considered a factor contributing to the legitimacy of a leader's authority.

The highest position of political authority was that of häkom. A häkom was a member of the hākomzāt class who controlled an agricultural center. The term was in origin usurped from the Persian administration before the end of the last century-possibly much earlier-and meant "governor." It is now strictly speaking obsolete, because the government no longer allows any formal recognition of the chiefs' status, but it continues to be used colloquially. Although the position depended to a large extent on the possession of certain personal qualities, it was inherited ideally, though by no means always in fact, by the eldest son from a wife of the same $z \bar{a} t$ or, failing that, from the same class. Before the Persian government took over the effective administration of the area, each häkom had a fort in the main agricultural center under his control. His income depended more on what he could control than on what he owned. It consisted of:

(I) The produce of land personally owned by him. This was worked by his own gholam, who received their keep, and/or sometimes local shahri who took a share of the harvest or some other compensation such as use of the hakkom's water for their own land.

(2) A tithe (dah-yak) on all agricultural produce of the shahri whom he controlled. These included all those in his center and those in a hinterland which varied according to his strength and prestige.

(3) Service (srēn-bandi) from all baluch who acknowledged his position. This could take many forms, as required, but was generally military or quasi-military.

(4) A tax (mäliyāt) from both shahri and baluch. This was in origin the tax due to the central government, but it was usurped by the hakom with the title. 


\section{EthNology}

The häkom no longer, of course, has any legal right to the last three of these items any more than to the title, but the concepts are still valid and the practices are still occasionally found. In particular, within the conceptual framework of sreen-bandi, the baluch are always ready to carry messages or run errands for the häkom. It is evident from the foregoing list that the häkom relied basically on a subject peasant population for their income, and on allegiance from nomadic pastoralists for their physical strength.

Not all communities, however, were involved with häkom, and some were involved only indirectly. Another type of leader is called sardär. No class distinction exists between a sardār and his following. He is always therefore either a shahri or a baluch, and thus by definition a class below a hakom. ${ }^{5} \mathrm{He}$ is ideally the senior member of the senior family of a tribe or group of subtribes, or in some cases of a community including representatives of different tribes. Where the tribe or community led by a sardār also owed allegiance to a häkom, as in perhaps the majority of cases, the häkom would confirm the appointment of the sardār by "tying on the turban," and in some cases he was able to influence the decision between rival candidates. Ideally the position of sardār is inherited in a similar manner to that of hakkm, and personal qualities are an important factor in both cases. The qualification of descent on the mother's side is probably less important for the sardär than for the $h \bar{a} k o m$, but this is difficult to confirm since there is less polygyny in sardar families, and where it occurs there is less class difference between wives of a sardär than between those of a häkom.

There are also communities which have no connection with either a häkom or a sardār and are led by a kamäsh. Whereas the term häkom is an Arabic word adopted from Persian during the last century, and sardär came from Persian probably not very much earlier, kamäsh comes from Brahui-a language of the Dravidian family, still spoken by minority groups, which almost certainly preceded Baluchi in the area. Originally it meant "greybeard." Now it has both an absolute and a relative usage. The politically senior man in any group, whether temporary or permanent, is referred to as the kamäsh of that group. Otherwise a kamäsh is any man who has the means and personal qualities to take on the responsibility of informal political representation for any number of other people, and in this sense the term may also be applied to sardār, häkom, and certain religious figures who seek to wield temporal authority. All men require the political representation of a kamäsh, who may be dependent on a sardār, or on a hăkom, or in certain rare cases may maintain freedom of action and be the paramount authority in a small area. A sardār may be independent, or dependent on a häkom.

As a general rule, it may be said that people of the shahri and $h a \bar{k}$ omzät classes are invariably cognatic, and that all baluch communities which have a traditional relationship with a hakkom also tend to be cognatically organized, whereas baluch tribes which have remained independent of $h \bar{a} k \mathrm{~km}$ are patrilineal. 
The basic means of livelihood, or subsistence techniques, in Persian Baluchistan vary between agriculture and pastoralism. But there is also a variation in the main domestic animal relied on (usually the camel or the goat), in staple crops (wheat, dates, rice, sorghum, beans), and in methods of irrigation. The variation in types of environment is even greater; for instance, the highest peak in the area has an elevation of more than 13,000 feet, whereas the lowest plains are at sea level. For the purposes of this article, however, the whole range of variation in environment and human ecology can be accounted for by applying the following three parameters: (I) the availability of water for agricultural use; (2) the level of technology at the command of the people who would use this water; (3) the coincidence of this water with cultivable soil.

Throughout the area direct rainfall is of negligible value, but one of the most important sources of water for irrigation is the run-off and wadi flooding which result from rainfall. The rainfall of a whole catchment basin is gathered by the nature of the terrain itself, with little or no human assistance, and is directed along with its invaluable sediment on to prepared fields. However, although a considerable volume of water is thus made available, the supply is extremely irregular and therefore does not in general support permanent settlement. In some parts wells are used, operated by hand by means of counterpoised water-lifts. In places where there is a shallow water table with a large catchment basin these can be reasonably reliable, but they nevertheless do not provide enough water to justify permanent agricultural settlement. In the mountain ranges which cross the southern part of the area many of the larger river beds in places retain flowing water throughout the year. Several of the agricultural centers of the area lie on such rivers, utilizing the alluvium which the river has deposited in a bend of its course. The larger settlements invariably contain the ruins of a fort and the residence of a $h \bar{a} k o m z \bar{a} t$ family.

There is one other method of obtaining water for irrigation which is used in the area, and this requires a much higher level of technological achievement than the methods mentioned so far. The Iranian plateau is the home of the qanāt system, ${ }^{6}$ but there are relatively few qanāt in Persian Baluchistan, and so far as I could ascertain none of them were dug by Baluch. The great advantage of a good qanät is that, once the capital investment has been made, the owner commands a continuous and reliable flow of water for irrigation in return for a relatively small annual outlay on maintenance and repair. A large proportion of the settled agriculture on the Iranian plateau would have been impossible (before the introduction of motor pumps) without qanāt. In Persian Baluchistan wherever there are old qanät (with the exception of one small region-Khāsh-where the agriculture was for some time controlled by non-Baluch) a häkomzāt family is associated with them, and there is consequently class differentiation in the community which lives off them.

In terms of the three parameters, the whole of Persian Baluchistan may be divided into regions which support a certain amount of settled agriculture and regions which support only varying numbers of (nomadic) pastoralists. Traditional settled agriculture is in most cases accompanied by the presence 


\section{I44 EthNOLOGY}

or control of a häkomzät family. One of the best ways of initiating settled agriculture on any scale in the area is to construct qanät. But qanät are not constructed by Baluch: Persian experts have to be brought in from the north or northwest.

\section{Spectal Cases}

Two special cases show partial transitions between the structural variants described above. The first of these concerns the people who call themselves Jadgāl and some other closely affiliated tribes which together make up the population of the extreme southeastern corner of Persian Baluchistan, just off the plateau on the coastal plain by the Gulf of Oman and the border with Pakistan. The Jadgāl claim to have immigrated from Sind some ten generations ago. Though used by other Baluch as a tribal appellation, the name is really a collective linguistic term which covers a number of tribes who speak Jadgāli, a language derived from Sindhi (though all male adults are also bilingual in Baluchi). Even though they retain an alien language, they are fully accepted as Baluch and call themselves Baluch in any larger context. The häkomzät family of this region is of the same origin but is now closely intermarried with neighboring hākomzāt families to the north and west, and its leading members no longer speak Jadgāli.

The ecology of the region is unique in Persia. The broad, flat plain is composed of layer upon layer of rich alluvial soil, brought down from the mountains by irregular flash floods. The water table is too deep to be accessible, even for modern motor pumps, so that regular irrigation is impossible. The people now depend on agriculture (irrigated from irregular flood water) and animal husbandry to an almost equal degree. Their flocks include sheep, goats, camels, cows, and water buffaloes, and a number of horses are still kept for riding purposes. The economy is, therefore, an unusually diversified one.

However, the leading branch of the häkomzät family now relies entirely on agriculture and no longer has any permanent residential center in the plain. There are two obvious and equally valid reasons for this. First, the rivers in the region have been cutting back rapidly during the last few decades, with the result that large areas of land that were previously intensively cultivated are now left without access to flood water. At the same time, there have been long periods of drought. Second, intermarriage of the leading members of the $h \bar{a} k o m z \bar{a} t$ (whose family name is Sardārzai) with neighboring häkomzāt on bilateral principles has provided them with good land in distinct neighboring ecological regions and with a following in these regions, for on the mother's side they now belong to the ruling häkomzāt families there as well. The Jadgāl, exclusive of the Sardārzai, are strictly and exclusively patrilineal. Not only do they give no inheritance to daughters, but they regard sons-inlaw as outsiders and never quite accept them into the in-group. Their suspicion of in-laws is carried to the extent that they refuse to intermarry with non-Jadgāl.

It appears that the Sardārzai were already differentiated from their people when they arrived in the region. After a while, fighting with the previous inhabitants of the region ended in a settlement and in intermarriage between 
the leading family of the immigrants and the hakkomzāt of the previous population. The Sardārzai were thus drawn into the cognatic network of häkom$z \bar{a} t$ intermarriage which extends today over most of Persian Baluchistan, became automatically members of the hākomzāt class, and thus gradually imported this class distinction and gave it validity among their own people. At the same time, because of the cognatic values of the people with whom they intermarried, they made their own economic (and political) position more secure by acquiring agricultural property through matrilateral inheritance in a another ecological region.

The leaders of the Sardārzai family have been conscious of their change to a cognatic orientation toward kin relationships. The reaction of the present hăkom and his father has been to attempt to persuade the Jadgāl both to intermarry with the neighboring tribes and to accord inheritance to daughters-but so far completely without success, even though such a course would give them shares in a distinct ecological region and to provide them with some security against drought in their own region. It is unfortunately no longer possible to judge whether this reaction of the hakkom was due to political awareness or to subconscious guilt for having deviated from the old ways. Their present stand is on justice and good. But this is also an imported value, for it is among the Baluch, not among the Jadgāl, that there is a strong, positive brother-sister relationship.

The second case concerns two large regions in Persian Baluchistan which are peopled by baluch who have remained for the most part aloof and independent from any $h \bar{a} k o m z \bar{a} t$ families, and are led by sardār of their own. One of these regions provides particularly interesting material in the present context. It is a large depression in the west of the area, generally called Jāz Muriān. The main tribe in this region is the Bāmeri, and for as far back as they can remember (which is only seven generations, probably marking the date of their entry into the region) the sardār of the tribe has been a member of the Nawābi family.

The Bāmeri claim that when they entered the depression there were no qanāt there. Those which now exist belong exclusively to the Nawābi and, according to local tradition, were started by that family at about the beginning of this century. Apart from the qanāt, a number of districts are cultivated by means of hand-operated wells. Whereas the lands irrigated from qanät belong to the sardār family and are worked by serfs and sharecroppers, the land irrigated from wells is owned and worked by individual free baluch. Moreover, generally and ideally land irrigated from wells provides only a supplementary source of livelihood.

The principal means of livelihood of the baluch of this depression is the camel; traditionally they have bred and trained what is probably the fastest and best riding camel in Persia. Since many of the wells are used solely for the watering of camels, and since even those who use them for cultivation still rely on camel rearing for their main livelihood, it seems likely that the wells were developed primarily as a means of watering the camels, rather than for agriculture. This ecological situation is quite different from the remainder of the area. 


\section{I46 Ethnology}

Until this century, therefore, there was no settled agriculture in the depression, and the region controlled by the sardār exhibited no class differentiation except for the limited use of gholäm. Since the qanät were constructed, a class distinction has arisen between gholam and sharecroppers, the economically independent baluch, and the landowning and ruling Nawābi. The Nawābi have sold their herds and have intermarried with the (non-Baluch) landowners in the Narmāshìr region to the northwest, but they still build no permanent dwellings.

Obviously the Nawābi today are in a social and political position equivalent to that of the hakkomzat in the remainder of the area, and the sardār of the Bāmeri is comparable to a häkom elsewhere. But he is not accorded the status or the title formally. This is not surprising, for the term is now after all an anachronism. It would, for instance, be illegal for him to attempt to collect dah-yak or mäliyät (though the more informal collections formerly allowed to sardār are still sometimes made despite their illegality). Similarly, it is understandable that the häkomzät in the remainder of the area are not quick to recognize a new member to their class. In the case of the Sardārzai, such recognition was forced on the häkomzät by military defeat, which also brought about intermarriage. Nevertheless, I have on one occasion heard the present sardār addressed as hākom by a Bāmeri sharecropper. Furthermore, the Bärakzai häkomzāt to the east have given a wife to the Nawābi. The mother of this woman was not häkomzät, and so the woman herself, though Bārakzai, did not have häkomzät class status, but the marriage is nevertheless significant in the present context.

Another geographical factor has been operative in this case. The whole of Baluchistan, in Afghanistan and Pakistan as well as in Persia, has tended historically to form a cul de sac. It is for the most part surrounded by desert on one side and an inhospitable coast on the other. The fact that it has never supported a large city, coupled with its general isolation, has meant that it has always been difficult to control, and that routes through it have seldom been secure. Until the r930s the main route of access to the area for Persian government officials lay through the Jāz Muriān depression, and the Persians always used a fort at the eastern end of the depression as their administrative center, when they could hold it. This meant that the Bāmeri, and particularly their leading family, the Nawābi, who controlled the route, were more exposed to contact and more open to influence from the rest of Persia than was the remainder of the area, and this probably helps to account for the construction of the qanät at the beginning of the present century. A few decades after the construction of the qanàt the new Pahlavi regime in Teheran (1925- ) sought to consolidate its position in the area by building a new provincial city at a site some 400 kilometers to the north. This resulted in the diversion of all through traffic away from the depression, and no motor road has yet been built through it. This has produced the paradox, that while the greater part of Persian Baluchistan has become progressively less isolated particularly during the last decade, the Jāz Muriān depression and its inhabitants the Bāmeri have suffered a net increase in isolation. This has allowed the Nawābi to take full advantage of the change in their situation at a time 
when $h \bar{a} k o m$ in the remainder of the area were being shorn of their privileges by the encroaching Persian administration. This is but one of many instances on the Iranian plateau of the effect that the choice of routes for motor roads, among other aspects of policies of modernization, may have on traditional balances of power and economic prosperity.

\section{Historical Reconstruction and a Model}

Baluch cultural values are basically nomadic pastoral values. A rich corpus of poetry exists in the Baluchi language which gives expression to these values. It is assumed that the people who brought the name Baluch to the area also brought the language. They were certainly pastoralists. There is no means of telling whether their descendants are among the present inhabitants of the area. The historical information which can be gleaned from the poetry belongs to a much later period.

The present population of the area may be conveniently divided into (I) the tribes who think they have always been there or profess not to know their origin, (2) those who claim to be by origin Arabs descended from Hamza, the paternal uncle of the Prophet Muhammad, and to have fought beside his grandson Husein at Karbala before migrating eastwards (though these are not Shi'a), and (3) those who claim a much more recent, and more likely, origin in Persia, Afghanistan, eastern Arabia, or the Indian subcontinent. Attention has already been drawn to the alien origin of most of the Baluchi terms introduced above. We may surmise that they were assimilated either because they were prestigious (e.g., hākom), or because they were brought into the society by high-status immigrants. Both oral tradition and such written historical evidence as exists indicate that the society has constantly assimilated immigrant groups, and that they have often entered the area with high status. It is to be expected that the assimilation of alien groups into the ruling class would bring with it new political concepts.

The model which is constructed below-which is similar to that expounded by Ibn Khaldun with reference to Islamic history up to the fourteenth century-is an attempt to complete the picture by suggesting the dynamic relationship between the two basic modes of livelihood, the two poles of political organization and kin behavior, and the various types of environment.

For reasons which concern their area of origin, a tribal, pastoral group of people invades a settled, agricultural area. They include a nuclear group which claims patrilineal descent from a common ancestor and recognizes within itself a dominant line or family, which, however, can only retain this position so long as it "earns" it by the quality of its leadership. Finding a power vacuum, owing to the weakness of the political structure and authority in the settled area it invades, it stays there and becomes the dominant power in the area. The leading family of the invaders becomes the focus of power in the settled area, and therefore the de facto rulers of both peoples: those that entered the area with it-the pastoralists-and those who were in the area when it came-the peasants. There may of course be more than one such family, in which case the area becomes divided into their respective areas of influence and political control. 


\section{EthNology}

Having become the focus of a more numerous and more diversified people, the leading family also increases in power and wealth, for it now has the use of agricultural as well as pastoral resources. The tribal following, however, does not become either more powerful or richer, since its social position has basically not changed; it follows the same way of life and feels the same relationship with its leading family as before. On the other hand, the settled people are now subordinate to the leading family of the invaders, and the structural distance between them and their new rulers is much greater than that which prevailed between the leading family and its tribal following. Finally, the direct relationship between the settled and the tribal people is not defined.

Before the invasion the settled people are unlikely to have had the same close relationship with their political leaders as the tribal following had with its dominant line. Being divided among a number of small villages over a large area, they are likely to have been politically subject to a "superstructure" of some kind, whether in the form of one single dominant "dynastic" family or of an oligarchy of several interrelated families (cf. Parsons I964: I62-I63; Spooner 1965: 23). In either case, the structural distance between the settled people and its rulers is likely to have been greater than that between the pastoralists and their leaders. In the new situation, therefore, as far as the settled people are concerned one superstructure is simply substituted for another, making little or no real difference to the social and political position of the great majority of them. The leaders who constituted their former superstructure will have been either killed, driven out, or assimilated with them. In the latter case, some of them may assume the role of popular leaders of their former people under the new superstructure. This is not so for the tribal following. For them the first main result of the new situation is to enhance their pride through contact with another stratum of people who are socially inferior to them (a) by occupation, for pastoral values are dominant, and (b) by structural distance from the rulers.

However, such a situation cannot be static, for it has enhanced the political and economic position of the leaders more than that of the following, with the result that the original tribal organization and the "group feeling" (cf. Ibn Khaldun 1958: passim) of the tribe is disturbed. The structural distance between the leading family and its tribal following automatically increases because of the change in the economic and political basis of that relationship. And the leading family tends to become "dynastic." Whatever may have been the situation before the invasion, the new composite population of the area is potentially divided into three social categories or classes: the dynastic family, the nomadic pastoralists, and the settled peasants. The relationship between the first and last of these is politically stable, but the relationships between the second and each of the other two tend to be unstable since neither is properly defined politically nor firmly based economically.

In the new situation the settled people are a source of agricultural wealth and labor for the dynastic family, while the tribal following is a source of military strength and, secondarily, of pastoral products. At first, the tribal following is by far the more important to the dynastic family because the latter 
stands in need of it as a source of strength to consolidate its position. But as its position becomes firmer, it looks more and more to the settled population as its main source of wealth.

Growing interest in settled agriculture, and therefore also in the settled agricultural people, causes the dynastic family next to change its military outlook. Whereas before it had fought for and defended movable property only, it is now interested in defending immovable plots of cultivable land and crops and peasants. With this in mind it begins to feel the nakedness and insecurity of nomad life and starts to build forts, or take over and develop existing ones, for its protection and defense in the main agricultural centers. It takes some time before the dynastic family becomes actually settled, but the forts are a tangible symbol for all three classes of the growing ties between the dynastic family and the settled people.

\section{Tribal Nomenclature and IDENTIty}

The model is capable of being developed further up to a cyclical stage of re-invasion (cf. Ibn Khaldun), with modifications to account for the new types of social change resulting from the intervention of the nationalist modernizing state machine. However, such further development is not required in connection with the argument of the present paper, and is left for a future publication. The remainder of this section discusses certain questions of tribal nomenclature and identity, and is parallel to the model.

Before arriving in the area the tribal people will have had a nameeither the original name of the agnatic nuclear group applied par excellence to the dynastic family or the original name of an eponymous ancestor of the dynastic family line applied by the tribal following to themselves, thus distinguishing them from other peoples by a name denoting their group allegiance. In either case this name is now gradually becoming applied to the settled people as well as the tribal following, i.e., in effect to the realm of the dynastic family. In short, the political unit takes its name from its dominant element, and the remainder of the population loses its ethnic or cultural identity, and thereby becomes fully assimilated.

Such is the case with regard to the situation within the society. The external situation, however, is somewhat different. The Persian Baluch are a political community to the extent that traditionally no tribe or group allowed themselves to become subordinated to non-Baluch. The concept of political unity under one (Baluch) leader has probably never had any general validity among them. What, then, is a Baluch? The simplest definition is that a Baluch is a man who calls himself "Baluch," since only the Baluch are proud of being Baluch. We can only improve on this by introducing the following hypothesis, which, though it is probably not susceptible of proof, takes account of the available evidence and throws some light on the situation under discussion.

The origin and etymology of the word "Baluch" are unknown. ${ }^{7}$ Among the Baluch today it is used, as we have already seen, simply to mean "tentdwelling pastoralist." It is significant that it is used with the same meaning in Persian in northeastern Persia. The words kurd and lur are reported to be 


\section{I50 EthNology}

similarly used among the Kurds and Lurs respectively, and similar usage of the word arab is also found among the Arabs. In some other parts of the Iranian world pairs of terms are found which are used to distinguish nomadic from settled people within a given area irrespective of ethnic or other factors. Such terms are often treated as though they have purely ethnic significance. The hypothesis I wish to suggest is that such words in general, and "Baluch" in particular, are in origin (so far as sociological rather than philological origin is concerned) terms adopted by settled populations to refer to bands of nomadic pastoralists who roamed the uncultivated land in their vicinity, regardless of their supposed racial origin or the language they spoke. As such "Baluch" would be a blanket "supra-tribal" term with associations of the town's fear and contempt of the wilderness. Because of the acknowledged cultural and religious superiority of the towns, it was natural for the nomads to accept the name (though without the associations) by which the townspeople designated them, thus unconsciously assimilating themselves to the town's conception of them. The nomads may also have their own term of contempt for the townspeople; for instance, for nontribal Persians Baluchi uses gajar, from the name of the last Persian dynasty. However, the townspeople would only assimilate themselves to the tribal conception of them if a tribal invasion were to conquer the towns and give rise to a tribal ruling class, as we have shown above.

Baluch society has retained a large percentage of nonnomads ${ }^{8}$ without losing the pastoral emphasis in its system of values. There is evidence to suggest that at an earlier stage in the development of the society the peasants were in a situation similar to helots. All the major agricultural centers of the area bear names which we know have remained unchanged since a time well before any people called Baluch arrived in the area. All other toponymy is predominantly Baluchi, and the exceptions are Persian and easily explained (cf. Spooner 1969). The pastoral invaders were interested in controlling the land and enjoying its produce, not in owning it. Even today land ownership is irrelevant to social status. There are several cases where the largest landowners (apart from the häkom) have a very low social status but a tribal name which means something like "chief." Such a situation is very difficult to explain unless such people do in fact represent the remnants of a previous agricultural population. They are now all fully assimilated as equal members of the society-as Baluch, though not as baluch. All named tribal groups in the Iranian cultural area (e.g., Bakhtiari, Qashqai, and Turkoman) include nonnomads, and it is natural that a term should be required to differentiate between nomadic and nonnomadic within the named group, whatever the origin of the latter. As we have seen, the same term is used in many cases for the nomadic as for the whole tribal group, and another is found for the nonnomads within it. In general, therefore, given the special ecological and historical factors of the Iranian cultural area, it would seem that within a given area the townspeople name the tribal group, whereas within the tribal group the nomads name the nonnomads. At each step the names are accepted with a certain degree of cultural inferiority.

The shift to cognatic principles of kinship, marriage, and inheritance 


\section{Politics, Kinship, and Ecology in Persia i5I}

helped to unify and fuse the two elements of the new society, the peasants and the pastoral immigrants. The horizontal network of cognatic intermarriage spread through most of the area, providing political alliance and agricultural security by the dispersal of landowning interests through two or more ecological regions. Only in two regions which remained almost entirely pastoral-the Jāz Muriān, discussed above, and the Sarhadd in the north of the area-was there little or no conversion from agnatic principles. The nomadic pastoralists of these two regions retained their independence from the agricultural $h \bar{a} k \mathrm{~km}$ by keeping themselves apart, rather than by superior strength. An endogamous, agnatic system of marriage and inheritance insured their independence, whereas the only use that the originally patrilineal hãkom retained for their agnatic genealogy was as a symbolic justification of their legitimacy.

\section{NOTES}

I. Between 1963 and 1967 I spent some fourteen months in Persian Baluchistan and most of the remainder of the time in Tehran in touch with informants. I take this opportunity of expressing my gratitude to St. Antony's College, Oxford, the British Academy, and the British Institute of Persian Studies for the financial and other assistance which made this possible, and to Dr. Rodney Needham for his generous guidance and encouragement.

2. Used in this sense the term is italicized with a small initial letter throughout. The distinction between Baluch and baluch is discussed in the final section. Briefly, all are Baluch in a context which includes non-Baluch; within Baluch society the term denotes this particular class.

3. This status was legally abolished when the administration of the area was formally taken over by the central government in 1928. The only practical difference this made at the time was to enable them to leave Baluch society if they wished. Those that now remain are almost exclusively black and/or Negroid, and an effective color bar makes it difficult for them to improve their status either within the area or elsewhere. Before I928 they were used as either domestic servants, agricultural serfs, or militia. The chiefs can no longer keep a militia, and they can no longer support many domestic servants. Apart from those who have moved to Karachi or the other side of the Persian Gulf as coolie laborers, many have been settled by their owners on part of their estate, often on a sharecropping basis.

4. With regard to inheritance it should be mentioned that the Baluch are Sunni Muslims of the Hanafi rite, and that according to Islamic law a daughter should receive half the share of a son, while certain provisions are also made for other relatives. There are a few small communities in the area, invariably with especial claims to religiosity, which keep strictly to these precepts. Inheritance practices also differ according to the type of property, but this will be dealt with in another publication.

5. To avoid confusion it should be noted that the general use of the term sardar outside the area under discussion, in both Baluchi and Persian, is to denote absolute or paramount tribal chiefs, similar to those here called hākom.

6. A good account is given in Wulff (1966: 249). Briefly, a qanät is an underground channel constructed to connect a reliable aquifer with cultivable land lower in the valley.

7. According to the general consensus of opinion the name "Baluch" and the Baluchi language were brought into the area from the northwest in the eleventh century, though the evidence is scanty. Most of what is now called Baluchistan probably did not become uniformly Baluch or Baluchi-speaking until much later. Practically nothing is known of what was displaced.

8. There are no figures. The proportion has probably varied constantly, since adverse circumstances, such as drought, tended to affect the baluch and drive them into tem- 


\section{EthNOLOGY}

porary or permanent exile before the shahri. The proportion of peasants to nomads is now probably more than half and increasing because of the bias of government development programs.

\section{BIBLIOGRAPHY}

Barth, F. 1962. The System of Social Stratification in Swat, North Pakistan. Aspects of Caste in South India, Ceylon and North-West Pakistan, ed. E. R. Leach, pp. II3-I46. Cambridge.

Ibn Khaldun. 1958. The Muqaddimah, trans. F. Rosenthal. 3 vols. New York.

Parsons, T. I95I (reprinted 1964). The Social System. Glencoe.

Spooner, B. 1965. Kinship and Marriage in Eastern Persia. Sociologus, n.s., I5: 22-3r.
1969. Notes on the Toponymy of the Persian Makran. Memorial Volume to Vladimir Minorsky. ed. C. E. Bosworth and J. Aubin (in press).

Wulff, H. E. Ig66. The Traditional Crafts of Persia. Boston. 